$\underline{A R T I C O L E}$

\title{
DUE PROCESS OF LAW: DISTORTION OF INTERPRETATION
}

DOI:10.24193/SUBBiur.63(2018).1.5

Published Online: 2018-03-20

Published Print: 2018-03-30

\section{P. RATHNASWAMY*}

\begin{abstract}
Law is wisdom of justice and justice is a beautiful instrument of convenience. Analytical interpretation is the embodiment of justice failing which it is left to extinction. Justice is granted and it is not permanent. Bad interpretation causes injury to justice and there is continuity of injustice. An institution is the source of interpretation. Is it insufficient for the elected institution to deliver justice? Does it debar the mind to be the judicial mind to deliver justice? Is it essential for independent judiciary to grant justice? Who is benefitted from justice? Who is at loss where there is denial of justice? What democracy has delivered to justice when dictatorship is blamed? Does denial of justice mean injustice or non-availability of justice? Does due process of law ensure justice to all or to a few? Is the due process of law custodian of justice? Wisdom is the rule of mankind and justice is the branch of wisdom. The custodian of justice is rarely found except in court. If the court is bargained who will be the gainer and who will be at peril. People have struggled several centuries in search of justice and it is the hard earned wealth of humanity. Many believe that it is in rule book of court. Due process is the source of rationality which is born out of wisdom. Many refer justice to invisible existence of faith and belief and it has been abused for power. It is broken by court and it has established norms and rules and it has been in rule of law. Due process is an objective wisdom and it is placed for debate and denial. Slowly it is affirmed to begin with the principles of existence so that there is truth to survive. Mere words do not form law unless these are recognised and accepted.
\end{abstract}

Keywords: Due Process Law, interpretation, distortion, judiciary, justices, skills, wisdom 


\section{Introduction}

Human history is the combination of justice and injustice. A few learn how to avail justice or to protect from injustice and the majority may not possess it. Law is the evolution of humanity. There are intuitions to deliver justice. It differs from institution to institution. There are Constitutional guarantees and there are institutional guarantees. The Constitution offers institutions to grant justice against injustice. There are laws which define justice. There are customary laws which guarantee justice. There are conventions and practices which grant justice. There may be individuals or a group of individuals or community or society to grant justice. What are the guidelines and principles to analyse wrongs or injustice and how did these principles evolve? My study is limited to due process of law.

The due process dates back to the declaration of Clause 39 of the Magna Carta in 1215. King John of England promised his people the protection of basic human rights. The due process principles are evident in equality before law and access to justice ${ }^{1}$. Due process of law has been instituted as Constitutional guarantee. The term 'due process of law' was first defined in 1354 in one of the Statutes of King Edward III. English rule institutionalized the definition and practice of due process of law in the world. James Madison drafted in 1788 the Due Process Clause. It became part of the Constitution of United States of America after changes and amendment as Bill of Rights in 1791. On ratification of the 14th Amendment in 1868 the Due Process Clause was included. The US Supreme Court is the institution to administer the Due Process Clause which provides four protections such as Substantive Due Process, Procedural Due Process, Prohibition against Vague Laws, and as a means to Bill of Rights. Substantive Due process deals with the personal liberties that are not listed in the Constitution. In order to decide the Court will ensure whether the issue is a fundamental right or otherwise. Procedural Due Process includes the right to fair trial, the right to reasonable opportunity, the right to present and know the evidence, the right to cross-examine and the right to defend through counsel or by himself. Prohibition against vague laws is the protection of citizens against vague laws and against the misuse of criminals under ignorance. 
India has adopted due process established by law as against due process of law. Article 21 of the Indian Constitution states 'No person shall be deprived of his life or personal liberty except according to procedure established by law'. However, in practice both due process of law of American Constitution and procedure established by law of Indian Constitution are mutually exchangeable. Due process of law has evolved over several centuries and it is a continuous process. It is called 'law of the land'. It is equally considered to be 'rational' or 'proportional'. Meanings and terms are indicating the dynamism of due process of law or due process clause. In simple words the term 'due' implies what is rational or proportional or essential or prerequisites or appropriate or normal. Each term refers to different meanings at various conditions and situations. In other words, much is left to reasoning and subjective. As a result, the interpretation remains always continuously changing and dynamic. There is a conflict of constitutional interpretation over a long period of time arguing the originalism over the living constitution and the living constitution over the originalism. The struggle is a constant confusion of conservatism over dynamism. No principle of law becomes the standard of law. If that happens wisdom of law is borrowed permanently allowing the humanity dies in cold storage of death knell. Man learns, and he learns always, continuously. When the learning is stopped the wisdom is dead wood. One-time learning confines the next day learning then it is the abuse of arrogance and stupidity. Learning and living are two sides of humanity and if either side is eclipsed then truth is the causality. Conviction and customs are stones for statues of tomorrow. The best knowledge is utopian interpretation as the knowledge leads with past glory towards new meaning and interpretation. It is said that the opinions of Justice Antonin Scalia are 'so consistent, so powerful, and so penetrating in their devotion to the rule of law-the real rule of law, not the political decrees of judges creating the so-called Living Constitution". ${ }^{2}$ The arguments of old Originalism and New originalism are making efforts to defend Originalism with different meaning and interpretation 3 . It is extraordinarily concluded if not completely that the Originalism is the constitutional history and Living Constitution is the Constitutional Theory. 4 The Originalism is the beginning but not the end. The Living Constitution is empty without Originalism. Enormous skills of interpretation are suggested 
to define Living Constitution as adaptability of law changing society and society changing law. 5 One of the greatest judges, Chief Justice John Marshall, has conclusively stated in Marbury vs. Madison ${ }^{6}$ that the written Constitution of America is constitutional document. It implies that it is the stone for statue. His judicial review is built upon it. Circumstances and situations are determining the interpretation. Time and wisdom too prevail upon the interpretation. Qualitative changes are invariable from time to time, person to person, institution to institution, Constitution to Constitution and governance to governance. Creativity and innovation are found in the interpretation for which the skills and competence are counted.

\section{Institution of Interpretation}

The Clause 17 of Magna Carta in 1215 holds that the 'Common pleas shall not follow our court but shall be held in some place'. There shall be an institution for justice and it is the court. It shall have permanent place. It has established the original intention to formulate institutionalization of justice. There was demand for local justice in Clauses 18 and 19 of Magna Carta. In order to establish justice there should be knowledge and skill of interpretation as found in the Clause 45 of Magna Carta ${ }^{7}$.

\subsection{Governance and Political Expedience}

Henry I of England limited his powers in 1100. Political agitation formed into Petition of Rights of 1628 and it limited the arbitrary power. There is the limitation of power to abuse. Judicial interpretation of Chief Justice Edward Coke was that the king and parliament were subject to law, common law, or law of the land. King Edward III declared that without due process of law there would not be deprivation of property, land, life and liberty. The decision of Supreme Court of America in Marbury vs Madison has usurped the judicial power of court even though it has become relative truth if not correct. It may appear to be judicious to uphold truth in the absence of ignition of power. The judicial review is a judicial power of the court defined in the Constitution. Despite the fact, the decision of Marbury 
v. Madison has provided conclusive force to judicial review. The judicial power is a part of judicial review, but the judicial review has to be administrated according to the powers sanctioned in the Constitution. The judicial power shall not exceed the power of judicial review, but it has been enlarged through judicial activism. There are decisions which are carved out of inherent power of the court on the interpretation of due process clause.

\subsection{India}

There was no mention of due process clause in Article 21 of the Indian Constitution. While drafting the Constitution there were discussions with judges and eminent Constitutional experts of United States of America and other nations during the visit of $\mathrm{BN} \mathrm{Rau}^{8}$ and deliberations held in the Constitutional Assembly on the inclusion or exclusion of Due Process Clause in the Constitution. Finally, it was decided to incorporate the procedure established by law in Article 21. There is a difference in the expression, but the difference is slowly eroded in the interpretation. The interpretation of the Constitution is the judicial function of the court, but it does not empower them to abuse under the guise and shadow of judicial interpretation. It may appear to be judicious unless there is evidence of truth and legality. The legality does not mean validity, but it includes justice. Injustice of many is also wrongfully and benignly enforced even though there is justice to a few. If the power is exceeded where is the remedy and who will enforce the remedy? The wrongful interpretation cannot be absolved at stages but in totality. The power of interpretation flows from the Constitution. The Supreme Court of India is the custodian of the Constitution and it is arbiter of the Constitution. Article 129 has the provision to exercise the inherent power to punish for contempt of itself. Article 129: 'The Supreme Court shall be a court of record and shall have all the powers of such a court including the power to punish for contempt of itself'. The Contempt of Court Jurisdiction is to uphold the dignity and majesty of law ${ }^{9}$ and to administer justice without interference ${ }^{10}$. The court of record is the evidentiary value of the records and it cannot be challenged in the court ${ }^{11}$. The inferences drawn from these decisions are unfortunately far away from the purpose and object of Article 129. The court of record refers to decisions and there will be 
punishment for wrong decisions as evinced under Art 137 that the Supreme Court has the power to review any judgment pronounced or order made by it since the Supreme Court is the final arbiter on the interpretation of the Constitution $^{12}$. In addition to it, the Supreme Court has inherent power to make any order for the ends of justice ${ }^{13}$, for rectifying mistakes of inadvertence $^{14}$, or by accidental and incidental ${ }^{15}$.

The Supreme Court has the power to refer to the Constitutional bench in this regard under the Proviso to Article $145(3)^{16}$. There is another provision of Article 140 which confers additional powers on the Supreme Court to enforce its decisions more effectively for which the Parliament may make suitable laws. The decisions of the Supreme Court form a source of law. The interpretations of the court are not only enforceable in the court of law but also, they become a source of law. Thus, the inherent powers to the Court are limited in Indian Constitution. Due Process Clause is found in the evolution of interpretation of the court.

Article $13^{17}$ of the Indian Constitution enumerates the power of judicial review. The reasonable restrictions are incorporated in art. 19 and the natural justice of the right to equality and equal protection are in art. 14 . The right to equality and equal protection are synthesis of natural justice. The natural justice and reasonable restrictions are the limitations to executives and legislature and whether these principles will be applicable to judiciary or otherwise. If such limitations are imposed on the judiciary who will be the arbiter and who will interpret them? The parties to dispute can become the parties to interpret and adjudicate or otherwise. Whether the due process clause is above law, or it is an abrogation to the power of interpretation? The due process clause has been growing in interpretation, but it appears to be omnipresent. The law is defined, drafted and enacted in the legislature but the due process clause is undefined resulting into subjective at the wisdom of interpretation.

Article 13 of the Indian Constitution had originally three sub-clauses, but the Sub-Clause 4 has been inserted in 1971 through $24^{\text {th }}$ Amendment to the Constitution.

The Supreme Court of India has interpreted that an amendment made to the Constitution of India under art. 368 is not a law under Article 13 
$(2)^{18}$. The Supreme Court of India has reversed its decisions ${ }^{19}$ and has declared Sub-Clause 4 of Article 13 void. Again, the Supreme Court of India has reversed the decision of Golak Nath's case and in Keshavananda Bharathi vs. State of Kerala ${ }^{20}$. Sub-Clause 4 to Article 13 was inserted in 1976 through $42^{\text {nd }}$ Amendment to the Constitution stating that no amendment of this Constitution, including Part III, shall be called in question in any court under any ground and this Sub-Clause 4 was declared void in Minerva Mills vs. Union of India ${ }^{21}$. The Supreme Court held that Sub-Clause 4, Article 13 purported to destroy the basic structure of the Constitution and it was declared void.

The decisions are the interpretations of the institution and the institution is created in the Constitution. These decisions are enforced. Individual wrong decisions are reprimanded but the institution is not reprimanded. Reversal of decision is punishment to the institution, but the enforced wrong decision has remained in force until suspended or removed. Article 368 of the Constitution has provided the power of amendment to the Constitution while invoking another Constitutional provision of Article 13 against it amounts to mismanagement of judicial power of interpretation. Does it amount to abuse of the judicial power or it supervenes the Constitutional authority sanctioned to them? Does it mean engaging them in controversial decision to benefit a few or misleading majority? Irrespective of the answers there is injustice. The basic structure theory has been propounded to demonstrate significant abuse of judicial power despite the fact that there is expansion of interpretation. Application of inconsistency is the benevolent distortion in interpretation. It perpetuates limitation to amendment power even though it has benefitted interpretation skills and has safeguarded Constitutionalism.

Article 14 of the Indian Constitution has twin objectives of equality before the law and equal protection of law and the Supreme Court of India has decided issues to uphold social and economic justice. ${ }^{22}$ The state shall not deny to any person equality before law and equal protection of law. The Court has interpreted narrowly. Article 17 abolishes untouchability and the Court has further narrowed down the interpretations. The untouchability is the social practice of discriminating people on the basis of caste. The Court has

\section{5}


liberally interpreted Articles 15 and 16. Article 15 promotes social harmony of prohibiting discrimination on grounds of religion, race, caste, sex, or place of worth. Article 16 provides equality of employment and reservation of employment to certain categories for promoting social justice. These articles are pertaining to social and economic conditions of backward class and most backward class on reservation policies of public employment including Scheduled Castes and Scheduled Tribes. The interpretations of the Court are consistently conservative and neither liberal nor dynamic. The reasons are comparable to a few and more groups of people. The untouchability is considered for a while, when the reservation for backward classes, Scheduled Castes and Scheduled Tribes has been considered. The reservation to SC and $\mathrm{S} \mathrm{T}$ has been construed as reverse discrimination but the same view has not been held for the other classes. There are data on the socio-economic indicators which are readily available, but the Court has failed to consider them. Thus, interpretations are comparable rather than judicious.

\subsection{Australia}

Australian due process principle has emerged from the principles of separation doctrine and it primarily focuses on the judicial power. There are few differences on the application of due process principle between USA and Australia. The principles of Due Process Clause in $4^{\text {th }}$ and $14^{\text {th }}$ Amendments expressly are incorporated in the American Constitution but not absent in Australian Constitution. ${ }^{23}$ It is found that 'The Separation of Powers as an implied Bill of Rights ${ }^{24}$.and it is in 'Section 177of the Constitution ${ }^{25}$. The due process is applied in judicial bodies of Australia and in case of American Constitution it is applicable in executive and judicial bodies. ${ }^{26}$ Chapter III of the Constitution imposes restrictions on legislation to transgress on the character, functions and powers of all the courts which are vested with Commonwealth judicial power. The procedural due process remains still unsettled in the Commonwealth Constitutions. The interpretations of Australian High Court in the cases of R.V. Kirby: Ex parte Boilermakers' of Society of Australia ${ }^{27}$, Nicholas v. The Queen ${ }^{28}$, Thomas v. Mowbray ${ }^{29}$, and Forge v. Australian Securities and Investments Commission ${ }^{30}$ have established Constitutional procedural due process principle. It is referred to 
the High Court's 'trial by jury' jurisprudence ${ }^{31}$. Slowly due process principle has been included in the Constitutional definition of judicial power. Australian High Court held that the due process principle is in the judicial power $^{32}$

The procedural due process standards include fair hearing, impartiality, cross examination, leading of evidence, and legal representation and these are the requirements of natural justice ${ }^{33}$. There is a distortion on the content of judicial power in Commonwealth due process principle in the absence of written Constitution in England. The member nations of commonwealth countries have accepted Privy Council as the highest institution of judiciary. Section 71 of the Australian Constitution provides meaningful resolution on Judicial Power, but the interpretation of judicial power continues to remain based on conventions and customary practices associated with judicial administration of England and it remains unsettled in Australia.

\subsection{USA}

Chief Justice John Marshall has asserted that the power of interpretation of an act of legislature, whether it is repugnant to the Constitution or otherwise, lies with the judiciary ${ }^{34}$. Justice Oliver Wendell Holmes has held that the character of every act depends upon the circumstances in which it is done'. ${ }^{35}$ It is found clearly that the minority rights are ignored at the behest of majorities who impose their will. Unfortunately, the Constitution is loosely interpreted as the former Justice Charles Evans Hughes has held: 'We are under the Constitution, but the Constitution is what the judges say it is'. The decision of Chief Justice Edward Coke of the British Court of Common Pleas in 1610 in the case of Dr. Bonham was considered as an antecedent of judicial review and the doctrine of substantive due process ${ }^{36}$. The decision was against the power of the London College of Physicians to imprison any person who practiced without license as it was considered against the common law right and reason. Such law was held void. The Supreme Court of America has decided to uphold injustice as against justice. African Americans were held not free and they were not American citizens in Dred Scott v. Sanford (1857). ${ }^{37}$ However this decision 
was overruled in view of the $13^{\text {th }}$ Amendment that prohibited slavery in US and in the view of the $14^{\text {th }}$ Amendment ${ }^{38}$, which brought equality. Justice Taney, supporter of slavery, held that the blacks are 'an inferior order and altogether unfit to with the white race'. The $14^{\text {th }}$ Amendment to the Constitution of America, on July 9, 1868 came into force. In the case of Plessy v. Ferguson (1896) ${ }^{39}$, the Supreme Court of America by 7-1 declined to recognise the principle of $14^{\text {th }}$ amendment but it interpreted as 'separate but equal'. After 60 years the Court has corrected the misdemeanour, in Brown v. Board of Education. ${ }^{40}$ The corporate political spending is held as a form of free speech which has excluded the application of campaign finance laws in Citizens United V. Federal Election Commission (2010) ${ }^{41}$. The Court has failed to decide on the accountability of prosecutor's office when an innocent man was languished in prison for 18 years in Connick v. Thomson (2011) ${ }^{42}$. The decision of the Court has diluted the Voting Rights Act of 1965 on the voters' suppression in Shelby County v. Holder $(2013)^{43}$. The Court has decided to reduce to 500 million dollars from 5 billion dollars damages of the biggest environmental disaster on the reasoning of exceeding compensatory ones in Exxon Shipping Co. v. Baker (2008) ${ }^{44}$.The majority of 5 to 4 decision of Presidential Election results allowing George W. Bush to White House was one of the worst decisions in Bush v. Gore (2000) $)^{45}$. The Electoral System of USA including the Presidential Election Law demands reforms to achieve electoral justice ${ }^{46}$ There are different views on this fateful decision of the Supreme Court of America. It is considered as a controversial decision or as a bad decision. The freedom of conclusion on any interpretation of legal issues should never be circumvented by inaccuracy of law. The Court held by majority 8-1 that the Civil Rights Act 1875 was not applicable to nongovernmental discrimination in The Civil Rights Cases $(1883)^{47}$ but it was reversed after 80 years in Atlanta Motel v. United States (1964). ${ }^{48}$ The Court has declined to recognize equality includes social equality in Plessy v. Ferguson (1896) ${ }^{49}$.There was dissenting opinion from Mr. Justice Harlan and he held: 'The arbitrary separation of citizens on the basis of race while they are on a public highway is a badge of servitude wholly inconsistent with the civil freedom and the equality before the law established by the Constitution. It cannot be justified upon any legal grounds'. He wrote further: 'Our 
Constitution is colorblind, and neither knows nor tolerates classes among citizens'.

\section{Conclusion}

Due process clause has not benefitted the justice unless it is interpreted correctly. The decisions of judges which are institutionalized in Courts may be suffering from otherwise of justice and the equality protection of the law and may result in distress. This is the mystery of the loss of due process clause. It is the optional exercise of judges. When the option is suitable to them they choose to opt for due process clause. It is unfortunate that the application of due process clause is natural law. Man decides what he thinks under the given circumstances outlined in the dynamic force of Theory of Morality. ${ }^{50}$ It is the essence of preservation of inequality to deny equal protection of the law. Man dominates for his supremacy over weak forces in which the survival of fittest is the rule while he is struggling for existence. Opportunities and challenges are threatening the domination. New ways are discovered to continue his domination giving different interpretation. John Marshall was threatened on his appointment and he discovered judicial review. It has proved to be the best. The Supreme Court of India has discovered, several times, the rule of Article 13 for judicial review in Golak Nath's Case and basic structure theory in Keshavananda Bharathi case. The Court under Constitution, as an institution, exceeds its proprietary through interpretation. Chief Justice Sir Edward Coke had differences with the King on his appointment and expressed in the case that law is above the King. It is welcomed and accepted by all. This is not on the application of due process clause. Equal protection of the law is not uniformly applicable to aliens and citizens in USA. The resident aliens within the territorial jurisdiction enjoy more Constitutional guarantees than the aliens outside the territorial jurisdiction. ${ }^{51}$.The Court has held that 'the Due Process Clause and Equal Protection Clause are universal in their application to all persons within the territorial jurisdiction without regard to any differences of nationality'. ${ }^{52}$ There is the importance of territorial presence of aliens but the $5^{\text {th }}$ and $14^{\text {th }}$ Amendments are never intended in this way53.

\section{9}


* Prof. P. Rathnaswamy PhD (Law), PhD (Mgt), DLitt (Mgt), Professor of Constitutional Law, Wollega University, Ethiopia, e-mail: drprswamy@gmail.com.

${ }^{1}$ Law Library of Congress, USA); Lord Thomas of Cwmgiedd (2015).

${ }^{2}$ Richard F. Duncan (2016), Justice Scalia and the rule of law: Originalism vs. the Living Constitution, College of Law, Faculty Publications, University of Nebraska-Lincoln.

3 Andrew Coan (2017), Living Constitutional Theory, Duke Law Journal Online, Volume 66 June 2017 pp. 101-104.

${ }_{4}^{4}$ Andrew Coan (2017), Living Constitutional Theory, Duke Law Journal Online, Volume 66 June 2017 pp. 112-114.

5 Vinay Harpalani (2015), Diversity and Living Constitution Theory, 2015 Constitution Day Symposium, American constitution Society.

${ }^{6} 5$ US. 1371803.

7 'We will not make justices, constables, sheriffs, or bailiffs who do not know the law of the land and mean to observe it well'.

${ }^{8} \mathrm{He}$ was appointed as Constitutional Adviser to the Constitutional Assembly of India, 1946. He prepared the draft Constitution of India in 1948.

9 Chetek Construction Ltd vs. Om Prakash (1998) 4 SCC 577; AIR 1998 SC 1955).

${ }^{10}$ Supreme Court Bar Association vs. Union of India (1998) 4 SCC 409; AIR 1895).

${ }^{11}$ State of Rajasthan vs. Mohan Singh (1995) SCC 153).

${ }_{12}$ P. Kannadasan vs. State of Tamil Nadu (1996) 5 SCC 670; AIR 1996 SC 2500).

${ }_{13}$ O XLVII, r, 6 of the Supreme Court Rules, 1966.

14 Rajender vs. Bijai (1836) 1 Moo PC 117.

${ }_{15}$ State of Mysore vs. Mysore Spinning \& Mfg. Co AIR 1958 SC 1002 (1006).

${ }_{16}$ Bekram Khurshid Pesikaka vs. State of Bombay (1955) 1 SCR 613: AIR 1955 SC 123.

${ }^{17}$ Article 13 (1) 'All laws in the territory of India immediately before the commencement of this Constitution, in so far they are inconsistent with the provisions of this Part, shall to the extent of inconsistency, be void.

(2) The State shall not make any law which takes away or abridges the rights conferred by this part and any law made in contravention of this clause, shall, to the extent of contravention, be void.

(3) In this Article, unless the context otherwise requires, ---

(a) "law" includes any Ordinance, order, bye-law, rule, regulation, notification, custom or usage, having in the territory of India, the force of law

(b) "laws in force" includes laws passed or made by a Legislature or other competent authority in the territory of India before the commencement of this Constitution and not previously repealed, notwithstanding that any such law or any part thereof may not be then in operation either at all or in particular areas

(4) Nothing in this article shall apply to any amendment of this Constitution made under article $368^{\prime}$.

${ }^{18}$ Shankari Prasad vs. Union of India (Shankari Prasad Sing Deo vs. Union of India, AIR 1951 SC 458) and Sajjan Singh vs. State of Rajasthan (AIR 1965 SC 845).

${ }^{19}$ Shankari Prasad vs. Union of India and Sajjan sing vs. Union of India in Golak Nath vs. State of Punjab (AIR 1967 SC 1643).

${ }^{20}$ AIR 1973 SC 1461. 
${ }^{21}$ (1980) 3 SCC 625: AIR 1980 SC 1789.

${ }^{22}$ Dalmia Cement (Bharat) Ltd vs. Union of India (1996) 10 SCC 104.

23 George Winterton (1994).

${ }^{24}$ Geoffrey Lindell (ed) Future Directions in Australian Constitutional Law: Essays in Honour of Professor Leslie Zines (1994) 185, 204-5.

25 Unfinished Rehabilitation' (1999) 27 Federal Law Review 393, 395-6.

${ }^{26}$ Erswin Chemerinsky (2nd Ed 2002), Constitutional Law: Principles and Policies, Ch 7, Gilbert V Homar, 520 US 924 (1997).

27 (1956) 94 CLR 254 (Boilermakers').

28 (1998) 193 CLR 173 ('Nicholas').

29 (2007) 233 CLR 307 ('Thomas').

30 (2006) 228 CLR 45 ('Forge').

${ }^{31}$ Will Bateman (2009).

${ }^{32}$ Chu Kheng Lim v. Minister for Immigration, Local Government and Ethnic Affairs (1992) 176 CLR1 ('Lim').

33 McGinty v. Western Australia (1996) 186 CLR 140, 231-2 (McHugh J).

34 Marbury v. Madison (1803).

35 Schenck v. United States (1919).

${ }^{36}$ Law Library of Congress (o74).

3760 US 3931857.

38 'All persons born or naturalized in the United States, and subject to the jurisdiction thereof, are citizens of the United states and of the State wherein they reside. No state shall make or enforce any law which shall abridge the privileges or immunities of citizens of the United States, nor shall any State deprive any person of life, liberty or property, without due process of law, nor deny to any person within its jurisdiction the equal protection of the laws'.

39163 U S 537 (1896).

${ }^{40} 347$ US 483 .

${ }^{41} 558$ US. 310 (2010).

$4^{4} 563$ US 51 (2011).

43570 US 2 (2013).

${ }^{44} 554$ US 471 (2008).

45531 US 98 (2008).

46 Rathnaswamy, P. (2004), Electoral Reform: Law and Institutions of India and world, Bookwell Publications, New Delhi, India; Rathnaswamy, P. (2014), Handbook on Election Law, LexisNexis, India.

47109 US 3 (1883).

${ }^{48} 515$, US December 14, 1964.

49163 US 537.

${ }^{50}$ Rathnaswamy, P. (1995). Marriage, Divorce and Morality, Deep and Deep Publications, new Delhi, India.

${ }^{51}$ Zadvyadas v. Davis, 533 U. S 678, 693 (2001).

$5^{2}$ Yick Wo v. Hopkins, 118 U.S 356, 359 (1886); Plyler v. Doe, 457 U.S 202, 210 (1982) - aliens owning property are persons under Fifth Amendment.

53 Austen Parrish (2006) Sovereignty, not due process: personal jurisdiction over nonresident, alien defendants, Wake Forest Law Review, Vol. 41, No. 1 Spring 2006.

\section{1}

